\title{
Review of the Use of Botulinum Toxin in the Setting of Back Pain
}

\author{
Jae H. Jung $\cdot$ Mark A. Bilezikjian
}

Published online: 16 March 2013

(c) Springer Science + Business Media New York 2013

\begin{abstract}
The current understanding of the pathophysiology of myofascial pain and the mechanism of botulinum neurotoxin (BoNT) suggest that BoNT may be well suited to the treatment of back pain. The few randomized controlled trials that have been done to evaluate the efficacy of BoNT in the treatment of myofascial low back pain have shown some promising results. Results from the more numerous trials of BoNT for treatment of myofascial thoracic and neck pain have only shown trends toward the efficacy of BoNT treatments compared with control treatments.
\end{abstract}

Keywords Botulinum toxin - Botox $\cdot$ Low back pain · Neck pain · Myofascial pain

\section{Introduction}

Back pain is associated with a significant socioeconomic and health impact. Health care expenditure for back pain in the USA was estimated at $\$ 90.7$ billion in 1998 [1]. The annual prevalence of low back pain ranges from 15 to $45 \%$. The resulting loss of productivity is evidenced by an average of nine workdays missed per year in the USA for individuals with back pain [2]. The incidence of neck pain

\footnotetext{
J. H. Jung $(\bowtie)$

Department of Orthopaedics, Physical Medicine and Rehabilitation, The UCLA Spine Center, David Geffen School of Medicine, 1250 16th Street, Suite 3145H, Santa Monica, CA 90404, USA

e-mail: jjung@mednet.ucla.edu
}

M. A. Bilezikjian

Physical Medicine and Rehabilitation, Johns Hopkins

School of Medicine, Baltimore, MD, USA

e-mail: mbilezi1@jhmi.edu over a 1-year period ranged from $27.1 \%$ in Norway to $47.8 \%$ in Quebec, Canada. Between 11 and $14 \%$ of workers were limited in their activities because of neck pain [3]. In 1990 there were almost 15 million visits to physicians' offices for "mechanical" low back pain [4]. Opioids are a common form of medical treatment for back pain. The mean annual prescription medication cost is eight times higher for opioid abusers versus nonabusers, $\$ 15,884$ versus $\$ 1,830$ [5]. The treatment and productivity costs associated with back pain have continued to rise despite an ongoing effort to describe the pathophysiology of different types of back pain and identify treatments with significant and lasting benefit.

Myofascial pain is defined as pain that originates from trigger points, taught bands of muscle that reproduce pain patterns on palpation. Myofascial pain can be present with or without other pain generators and often causes referred pain to the surrounding muscles. The cause of myofascial pain is controversial, but studies have elucidated at least part of the pathophysiological mechanism involved. Pertinent to this review are the findings of a pathological increase in the release of acetylcholine ( $\mathrm{ACh}$ ) by the nerve terminal evidenced in electrodiagnostic studies of the affected resting muscle [6॰]. A positive-feedback loop has been proposed to explain the persistence of increased $\mathrm{ACh}$ release by involved trigger points. In the proposed feedback loop, local ischemia and increased metabolism are caused by sustained sarcomere contraction leading to energy crisis of the tissue. Release of sensitizing substances then generates pain and propagates increased ACh release [6•]. Botulinum neurotoxin (BoNT) inhibits the release of ACh from the nerve terminal and so theoretically should be able to interfere with the proposed positive-feedback loop.

BoNT has been investigated in the treatment of back pain, muscle disorders, and headaches. It has been shown to be effective in the treatment of cervical dystonia by 
relieving both muscle spasticity and pain [7]. The mechanism of BoNT has been well demonstrated as muscle relaxation, but studies also suggest a separate analgesic mechanism through inhibition of the release of substance $P$ [8]. The following is a review of the literature on the efficacy of BoNT in the treatment of back pain.

\section{Literature Search}

The electronic literature was searched using the keywords "botulinum toxin, " "Botox," "low pack pain," "neck pain," and "myofascial pain" in the PubMed database.
Additional studies were included after reviewing the bibliographies of relevant articles. Studies were excluded from this review if they were not randomized controlled trials (RCTs) comparing BoNT with alternative treatments or if they included subjects with fibromyalgia or subjects with pain generators other than myofascial pain. The literature was searched up to February 1, 2013.

\section{Low Back Pain}

Few RCTs of intramuscular injections of BoNT for the treatment of low back pain have been performed (Table 1).

Table 1 Summary of randomized controlled trials of intramuscular injections of botulinum neurotoxin (BoNT) for the treatment of low back pain

\begin{tabular}{|c|c|c|c|c|}
\hline Study & Methods & Participants & Interventions & Outcomes \\
\hline De Andres et al. $\left[9^{\bullet}\right]$ & $\begin{array}{l}N: 28 \\
\text { Dropouts: } 1 \\
\text { RCT } \\
\text { Double blind }\end{array}$ & $\begin{array}{l}\text { Chronic low back pain } \\
\text { with bilateral trigger } \\
\text { points and duration } \\
\text { longer than } 6 \text { months }\end{array}$ & $\begin{array}{l}\text { For each participant, } 50 \mathrm{U} \\
\text { BoNT-A was administered to } \\
\text { affected muscles on one side } \\
\text { and either } 0.9 \% \mathrm{NaCl} \text { or } \\
0.25 \% \text { bupivacaine was } \\
\text { administered to muscles on } \\
\text { the other side. Randomization } \\
\text { was performed both for the } \\
\text { side into which BoNT was } \\
\text { injected and for the opposite } \\
\text { side, for which control } \\
\text { injectant was used . Overall, } \\
\text { BoNT was injected into } 88 \\
\text { muscles, including psoas } \\
\text { (18.5\%), quadratus } \\
\text { lumborum (18.5\%), and } \\
\text { psoas and quadratus } \\
\text { lumborum (63\%) }\end{array}$ & $\begin{array}{l}\text { Evaluation by the VAS at } 15, \\
30, \text { and } 90 \text { days after } \\
\text { treatment. No statistically } \\
\text { significant difference }\end{array}$ \\
\hline Fishman et al. $\left[10^{\bullet}\right]$ & $\begin{array}{l}N: 87 \\
\text { Dropouts: } 20 \\
\text { RCT } \\
\text { Double blind } \\
3 \text { groups }\end{array}$ & $\begin{array}{l}\text { Sciatica diagnosed by } \\
\text { physical examination } \\
\text { and electromyogram }\end{array}$ & $\begin{array}{l}\text { All groups received standard } \\
\text { physical therapy twice } \\
\text { weekly for } 12 \text { weeks. Both } \\
\text { groups received injections of } \\
20 \mathrm{mg} \text { triamcinolone and } \\
2 \% \text { lidocaine into the } \\
\text { pirifomis muscle. The trial } \\
\text { group also received } 300 \mathrm{U} \\
\text { BoNT-A }\end{array}$ & $\begin{array}{l}\text { VAS evaluation reported every } \\
2 \text { weeks for } 12 \text { weeks. } \\
\text { Patients with } 50 \% \text { or more } \\
\text { improvement on the VAS at } \\
\text { their last } 2 \text { visits: } 65 \%(13 / \\
21) \text { of patients treated with } \\
\text { BoNT; } 32 \%(10 / 31) \text { of } \\
\text { patients treated with } \\
\text { triamcinolone/lidocaine; } 6 \% \\
\text { (1/15) of patients treated with } \\
\text { placebo. Statistically } \\
\text { significant difference }\end{array}$ \\
\hline Foster et al. $\left[11^{\bullet}\right]$ & $\begin{array}{l}N: 31 \\
\text { Dropouts: } 3 \\
\text { RCT } \\
\text { Double blind } \\
2 \text { groups }\end{array}$ & $\begin{array}{l}\text { Lateralizing low back } \\
\text { pain between L1 and } \\
\text { S1 lasting more than } \\
6 \text { months }\end{array}$ & $\begin{array}{l}\text { Participants were randomized } \\
\text { to receive either } 200 \mathrm{U} \text { BoNT } \\
\text { (40 U per site) or saline } \\
\text { injections of identical } \\
\text { volumes into L1-L5 } \\
\text { paravertebral muscles on the } \\
\text { more painful side. BoNT was } \\
\text { injected into L2-S1 } \\
\text { paravertebral muscles if pain } \\
\text { extended to the sacral area }\end{array}$ & $\begin{array}{l}\text { VAS and OLBPQ were } \\
\text { evaluated for more than } 50 \% \\
\text { pain reduction after the } \\
\text { procedure: at } 3 \text { weeks, } \\
73.3 \%(11 / 15) \text { of the BoNT } \\
\text { group and } 25 \%(4 / 16) \text { of the } \\
\text { saline group; at } 8 \text { weeks, } \\
66.7 \%(10 / 15) \text { of the BoNT } \\
\text { group and } 18.8 \%(3 / 16) \text { of } \\
\text { the saline group. Statistically } \\
\text { significant difference }\end{array}$ \\
\hline
\end{tabular}


The subjects included in these three studies had low back pain or symptoms of sciatica for over 6 months. The acute and subacute low back pain populations were not represented in these studies.

The studies of Foster et al. [11•] and De Andres et al. [9॰] enrolled patients with myofascial low back pain. These two studies targeted different muscles with the BoNT injections, paraspinal muscles in one study and quadratus lumborum and psoas muscles in the other study. Similar doses of BoNT were used in the two studies. The subjects in the study of Fishman et al. [10•] had symptoms of sciatica and piriformis syndrome; the piriformis muscle was therefore targeted for BoNT injections. Although De Andres et al. [9•] performed injections bilaterally, BoNT was only injected unilaterally in the study of Fishman et al. Similarly, Foster et al. [11•] injected BoNT unilaterally, but there was no intervention on the contralateral side.

Fishman et al. [10॰] and Foster et al. [11•] both found a statistically significant reduction in pain on a visual analog scale (VAS) when compared with the control groups. De Andres et al. [9॰] did not find a statistically significant reduction in back pain as measured by the VAS reported for the BoNT-treated side the versus saline-treated side.

\section{Thoracic and Neck Pain}

The studies included in Table 2 are all RCTs, but their power, methods, and outcomes are quite different. All studies focused on enrolling participants with chronic myofascial pain, but the participants differed widely in the severity of pain and number of trigger points reported and treated. Each study had at least one outcome measure that was a subjective rating scale, including a VAS, an efficacy of treatment verbal scale, and a pain self-rating scale. Additional outcomes could not be compared given the wide variety of measures reported, including SF-36, number of analgesics used per day, pressure pain thresholds, Beck Depression Inventory, number of days/weeks without pain, and Neck Disability Index. Some of these additional outcomes showed promising trends or statistical significance in favor of BoNT treatment, such as taking less analgesic medication per day (Schnider et et al. [18]), having fewer days with pain per week (Gobel et al. [15]), and improvements on the SF-36 (Lew et al. [16]).

No study showed an overall statistically significant difference between treatment and control groups. Gobel et al. [15••] reported a short period of statistically significant

Table 2 Summary of randomized controlled trials of intramuscular injections of BoNT for the treatment of thoracic and neck pain

\begin{tabular}{|c|c|c|c|c|}
\hline Study & Methods & Participants & Interventions & Outcomes \\
\hline Cheshire et al. [12] & $\begin{array}{l}N: 6 \\
\text { Dropouts: } 0 \\
\text { RCT Double blind } \\
\text { Crossover }\end{array}$ & $\begin{array}{l}\text { Myofascial pain for } \\
2-4 \text { years }\end{array}$ & $\begin{array}{l}\text { Two injections, one BoNT-A, } \\
\text { the other saline, performed } \\
8 \text { weeks apart in random } \\
\text { order. } 50 \text { U BoNT was } \\
\text { distributed at } 2-3 \text { sites }\end{array}$ & $\begin{array}{l}4 \text { of } 6 \text { participants from the } \\
\text { BoNT group "responded" } \\
\text { (had improvement of } 30 \% \text { or } \\
\text { greater in VAS scores in at } \\
\text { least } 2 \text { of the } 5 \text { weeks } \\
\text { evaluated). } 1 \text { of } 6 \text { patients did } \\
\text { not respond and } 1 \text { of } 6 \\
\text { patients responded to both } \\
\text { BoNT and saline. No } \\
\text { statistically significant } \\
\text { difference }\end{array}$ \\
\hline Esenyel et al. [13] & $\begin{array}{l}N: 90 \\
\text { Dropouts: } 0 \\
\text { RCT } \\
\text { Not blind } \\
5 \text { groups }\end{array}$ & $\begin{array}{l}\text { Unilateral myofascial } \\
\text { pain with trigger } \\
\text { points in the trapezius } \\
\text { for more than } \\
6 \text { months }\end{array}$ & $\begin{array}{l}\text { Groups 1-4 all undertook } 15 \\
\text { stretching exercise sessions } \\
\text { Group 1: } 10 \text { U BoNT-A into a } \\
\text { single trigger point, once } \\
\text { Group 2: Lidocaine }(0.5 \%) \\
\text { into one trigger point, once } \\
\text { Group 3: Conventional } \\
\text { ultrasound to trigger points, } \\
\text { 15 sessions } \\
\text { Group 4: High power pain } \\
\text { threshold ultrasound, } 15 \\
\text { sessions } \\
\text { Group 5: Control-stretching } \\
\text { exercises only }\end{array}$ & $\begin{array}{l}\text { VAS scores evaluated before } \\
\text { treatment and at } 1 \text { week and } \\
1 \text { month after treatment No } \\
\text { statistically significant } \\
\text { difference (at } 4 \text { weeks, } \\
\text { improvement in VAS scores } \\
\text { from BoNT was only found } \\
\text { to be statistically significant } \\
\text { compared with high power } \\
\text { pain threshold ultrasound) }\end{array}$ \\
\hline
\end{tabular}


Table 2 continued

\begin{tabular}{|c|c|c|c|c|}
\hline Study & Methods & Participants & Interventions & Outcomes \\
\hline Ferrante et al. [14] & $\begin{array}{l}N: 132 \\
\text { Dropouts: } 0 \\
\text { RCT } \\
\text { Double blind } \\
\text { 2-week washout } \\
\text { Dose response } \\
2 \text { groups }\end{array}$ & $\begin{array}{l}\text { Myofascial } \\
\text { cervicothoracic pain } \\
\text { with } 1-5 \text { trigger points } \\
\text { for at least } 6 \text { months }\end{array}$ & $\begin{array}{l}\text { Single injection trial of } 10,25, \\
\text { or } 50 \text { U BoNT-A or saline } \\
\text { into each trigger point. All } \\
\text { patients received scheduled } \\
\text { amitriptyline and ibuprofen } \\
\text { and propoxyphene/acetami- } \\
\text { nophen as needed. All } \\
\text { patients received myofascial } \\
\text { release physical therapy } \\
\text { throughout the study }\end{array}$ & $\begin{array}{l}\text { VAS scores were obtained } \\
\text { weekly for } 8 \text { weeks following } \\
\text { injections. All groups had } \\
\text { improved VAS scores } \\
\text { compared with the baseline. } \\
\text { No statistically significant } \\
\text { difference }\end{array}$ \\
\hline Gobel et al. $[15 \bullet \bullet]$ & $\begin{array}{l}N: 145 \\
\text { Dropouts: } 25 \\
\text { RCT } \\
\text { Double blind } \\
2 \text { groups }\end{array}$ & $\begin{array}{l}\text { Moderate to severe } \\
\text { upper back myofascial } \\
\text { pain syndrome with } 10 \\
\text { or more trigger points } \\
\text { and pain for } \\
6-24 \text { months }\end{array}$ & $\begin{array}{l}\text { Either } 0.9 \% \mathrm{NaCl} \text { or } 40 \mathrm{U} \\
\text { BoNT-A was injected into } \\
\text { the } 10 \text { most painful trigger } \\
\text { points at each site }\end{array}$ & $\begin{array}{l}\text { Subjects were followed up } \\
\text { every } 4 \text { weeks for } 12 \text { weeks. } \\
\text { Pain was rated on the ordinal } \\
\text { pain self-rating scale. Pain } \\
\text { diaries were kept from week } \\
1 \text { to week } 12 \text {. No statistically } \\
\text { significant difference (from } \\
\text { week } 5 \text { to week } 8 \text {, a } \\
\text { statistically significant } \\
\text { difference was reached) }\end{array}$ \\
\hline Lew et al. [16] & $\begin{array}{l}N: 29 \\
\text { Dropouts: } 0 \\
\text { RCT } \\
\text { Double blind } \\
2 \text { groups }\end{array}$ & $\begin{array}{l}\text { Myofascial upper back } \\
\text { pain diagnosed within } \\
2-6 \text { months and } \\
\text { current pain score of } 5 \\
\text { or greater (VAS) upon } \\
\text { enrollment }\end{array}$ & $\begin{array}{l}1-4 \text { muscles were injected with } \\
50 \mathrm{U} \text { BoNT or } 0.9 \% \mathrm{NaCl} \text {. } \\
\text { No more than } 2 \text { muscles per } \\
\text { side were injected }\end{array}$ & $\begin{array}{l}\text { Follow up at } 0 \text { and } 2 \text { weeks and } \\
\text { at } 1,2,3,4 \text {, and } 6 \text { months } \\
\text { after injection. The } 1 \text { st two } \\
\text { follow-ups were in person. } \\
\text { The last five were by mail. } \\
\text { (For } 26 \% \text {, data were not } \\
\text { reported.) No statistically } \\
\text { significant difference }\end{array}$ \\
\hline Ojala et al. [17] & $\begin{array}{l}N: 31 \\
\text { Dropouts: } 0 \\
\text { RCT } \\
\text { Double blind } \\
\text { Crossover }\end{array}$ & $\begin{array}{l}\text { Pain in neck and } \\
\text { shoulder region for } \\
\text { more than } 2 \text { months. } \\
\text { Clinical diagnosis of } \\
\text { myofascial pain }\end{array}$ & $\begin{array}{l}\text { Either saline or } 5 \text { U BoNT-A } \\
\text { was injected into } 3-7 \text { trigger } \\
\text { points as the } 1 \text { st intervention. } \\
\text { After } 4 \text { weeks, crossover } \\
\text { injections were performed }\end{array}$ & $\begin{array}{l}\text { Follow up at } 4 \text { weeks after the } \\
1 \text { st injection and } 4 \text { weeks } \\
\text { after the crossover injection. } \\
\text { Efficacy of treatment verbal } \\
\text { scale reported. No } \\
\text { statistically significant } \\
\text { difference }\end{array}$ \\
\hline Schnider et al. [18] & $\begin{array}{l}\text { N: } 33 \\
\text { Dropout: } 0 \\
\text { RCT } \\
\text { Double blind } \\
\text { two groups }\end{array}$ & $\begin{array}{l}\text { Diagnosis of cervical } \\
\text { headache; } \\
0.5-30 \text { years of } \\
\text { symptoms with trigger } \\
\text { points }\end{array}$ & $\begin{array}{l}\text { Both groups received } \\
\text { standardized physical therapy } \\
\text { for } 9 \text { sessions. } 6 \text { trigger points } \\
\text { were treated with } 15 \mathrm{U} \text { BoNT } \\
\text { per site or with } 0.9 \% \mathrm{NaCl}\end{array}$ & $\begin{array}{l}\text { Headache and muscle } \\
\text { tenderness diaries were kept } \\
\text { for } 16 \text { weeks after injections. } \\
\text { The VAS scale was used for } \\
\text { headaches and pressure pain } \\
\text { threshold was measured for } \\
\text { trigger points. Data were } \\
\text { reported for successive } \\
\text { 4-week periods for } 16 \text { weeks. } \\
\text { No statistically significant } \\
\text { difference }\end{array}$ \\
\hline
\end{tabular}

difference in the mean reduction of pain scores between the two groups studied from week 5 to week 8. This study was the highest powered and this result is consistent with the expected time of onset and maximum effect of BoNT, making it a potentially positive result for comparative efficacy of BoNT. From the results of Gobel et al. from a clinical relevance standpoint, the overall improvement in VAS score at 4 weeks was $30 \%$ for the BoNT group and $17 \%$ for the saline group. A13 percentage point difference in mean VAS score between the two groups, although statistically significant, may not be clinically significant. Fortunately, mean scores do not predict the potential for clinically relevant response to treatment for an individual.

\section{Conclusions}

Despite the small number of patients treated in the RCTs of intramuscular injections of BoNT for the treatment of low back pain, two of the three studies discussed showed 
statistically significant improvement in VAS scores as compared with placebo injections. Aggregate data cannot be evaluated owing to a large difference in study methodology and heterogeneous patient selections. Additional studies with higher power should be performed to evaluate the validity of existing methodology before new methods are studied given the reported clinical success.

Compared with low back pain, a larger number of patients have been treated in RCTs of intramuscular injection of BoNT for the treatment of myofascial neck and upper back pain. In many cases both BoNT and control treatments produced more than $30 \%$ improvement in subjective pain scores compared with baseline scores. Reports on the comparative efficacy of BoNT and control treatments have only shown trends toward the superiority of BoNT. These results may indicate that the physiologic effects of BoNT on the myofascial pain process are not as important as the simple intervention of needling or injection of $\mathrm{NaCl}$ or lidocaine. They could also indicate a poor understanding of which subpopulation of patients with myofascial pain will respond to BoNT. The methods varied widely in BoNT dose, co-interventions, pain severity, chronicity, and number of trigger points treated, so aggregate data evaluation would not be meaningful. Further studies of BoNT treatment for myofascial neck and upper back pain may be able to better characterize the optimal treatment population, dose, and method of administration. It appears that only a small subpopulation of patients with myofascial neck and upper back pain may receive comparative benefit from BoNT treatment given the lack of a statistically significant difference found in multiple studies.

Disclosure J.H. Jung declares no conflict of interest and M.A. Bilezikjian declares no conflict of interest.

\section{References}

Papers of particular interest, published recently, have been highlighted as:

- Of importance

-• Of major importance

1. Luo X, Pietrobon R, Sun SX, Liu GG, Hey L. Estimates and patterns of direct health care expenditures among individuals with back pain in the United States. Spine (Phila Pa 1976). 2004;29(1):79-86.

2. Manchikanti L, Singh V, Datta S, Cohen SP, Hirsch JA. Comprehensive review of epidemiology, scope, and impact of spinal pain. Pain Physician. 2009;12(4):E35-70.

3. Cote P, van der Velde G, Cassidy JD, Carroll LJ, Hogg-Johnson S, Holm LW, et al. The burden and determinants of neck pain in workers: results of the Bone and Joint Decade 2000-2010 Task
Force on Neck Pain and Its Associated Disorders. Spine (Phila Pa 1976). 2008;33(4 Suppl):60-74.

4. Hart LG, Deyo RA, Cherkin DC. Physician office visits for low back pain. Frequency, clinical evaluation, and treatment patterns from a U.S. national survey. Spine (Phila Pa 1976). 1995;20(1): $11-9$.

5. Manchikanti L. Health care reform in the United States: radical surgery needed now more than ever. Pain Physician. 2008;11(1): $13-42$.

6. - Borg-Stein J, Simons DG. Focused review: myofascial pain. Arch Phys Med Rehabil. 2002;83(3 Suppl 1):S40-7, S48-9. The positive-feedback loop cited in this article is based on scientific studies but is theoretical. It is not meant to be a stand-alone explanation of the only mechanism of myofascial pain but rather a key component that may be targeted in treatment.

7. Jankovic J, Schwartz K. Botulinum toxin injections for cervical dystonia. Neurology. 1990;40(2):277-80.

8. Ishikawa H, Mitsui Y, Yoshitomi T, Mashimo K, Aoki S, Mukuno K, et al. Presynaptic effects of botulinum toxin type A on the neuronally evoked response of albino and pigmented rabbit iris sphincter and dilator muscles. Jpn J Ophthalmol. 2000;44(2): 106-9.

9. - De Andres J, Adsuara VM, Palmisani S, Villanueva V, LopezAlarcon MD. A double-blind, controlled, randomized trial to evaluate the efficacy of botulinum toxin for the treatment of lumbar myofascial pain in humans. Reg Anesth Pain Med. 2010;35(3):255-60. This is the only study involving treatment with both BoNT and saline as a control at the same time (on opposite sides) as opposed to using a crossover study design. This was a novel approach to eliminate the inter-rater differences in VAS reporting and the potential effect of a difference in treatment order that may occur in RCTs and crossover studies.

10. • Fishman LM, Anderson C, Rosner B. BOTOX and physical therapy in the treatment of piriformis syndrome. Am J Phys Med Rehabil. 2002;81(12):936-42. Although this article was not on myofascial pain, it was considered in this review as a related and relevant $R C T$ in a very small body of literature.

11. - Foster L, Clapp L, Erickson M, Jabbari B. Botulinum toxin A and chronic low back pain: a randomized, double-blind study. Neurology. 2001;56(10):1290-93. This is the only RCT in the literature that resulted in a statistically significant difference between VAS scores reported by subjects receiving BoNT injections for treatment of myofascial pain and a control group receiving normal saline injections.

12. Cheshire WP, Abashian SW, Mann JD. Botulinum toxin in the treatment of myofascial pain syndrome. Pain. 1994;59(1): $65-9$.

13. Esenyel M, Aldemir T, Gursoy E, Esenyel C, Demir S. Myofascial pain syndrome: efficacy of different therapies. J Back Musculoskelet Rehabil. 2007;20(43):7.

14. Ferrante FM, Bearn L, Rothrock R, King L. Evidence against trigger point injection technique for the treatment of cervicothoracic myofascial pain with botulinum toxin type A. Anesthesiology. 2005;103(2):377-83.

15. - Gobel H, Heinze A, Reichel G, Hefter H, Benecke R, Dysport myofascial pain study group. Efficacy and safety of a single botulinum type A toxin complex treatment (Dysport) for the relief of upper back myofascial pain syndrome: results from a randomized double-blind placebo-controlled multicentre study. Pain. 2006;125(1-2):82-8. This was the largest RCT, included injection into the largest number of trigger points, and used the highest total dose of BoNT. It was also the only one to reach statistical significance for part of the follow-up period. 
16. Lew HL, Lee EH, Castaneda A, Klima R, Date E. Therapeutic use of botulinum toxin type A in treating neck and upper-back pain of myofascial origin: a pilot study. Arch Phys Med Rehabil. 2008;89(1):75-80.

17. Ojala T, Arokoski JP, Partanen J. The effect of small doses of botulinum toxin a on neck-shoulder myofascial pain syndrome: a double-blind, randomized, and controlled crossover trial. Clin J Pain. 2006;22(1):90-6.

18. Schnider P, Moraru E, Vigl M, Wober C, Foldy D, Maly J, et al. Physical therapy and adjunctive botulinum toxin type $\mathrm{A}$ in the treatment of cervical headache: a double-blind, randomised placebo-controlled study. J Headache Pain. 2002;3(93):9. 